\title{
Comparison of corrosion inhibitor performance based on green corrosion inhibitor of extract leaf tobacco and commercial imidazoline inhibitor in a sweet environ- ment at carbon steel AISI 1045 in $\mathrm{NaCl} 3.5 \%$ solution
}

\author{
Mochamad Alvan Mifta Chusururi ${ }^{1 *}$, Dendra Ravelia ${ }^{2}$, Brahmanu Wisnu Saputro ${ }^{3}$, Fikri Nafi'ul \\ Ahmadi ${ }^{4}$, Lukman Noerochiem ${ }^{5}$, Budi Agung Kurniawan ${ }^{6}$
}

1, 2, 3, 4, 5, 6 Sepuluh Nopember Institute of Technology, Surabaya, Indonesia

\section{Keywords \\ $\mathrm{CO}_{2}$ \\ Corrosion \\ Imidazoline inhibitor \\ AISI 1045}

Received: 4 December 2017 Accepted: 16 Jaunary 2018 Published: 7 February 2018

\begin{abstract}
This study evaluates the performance of an imidazoline commercial inhibitor in a sweet environment. AISI 1045 carbon steel was chosen, with $\mathrm{pH} 5$ and pH 7, flow rate $7.85 \mathrm{~cm} / \mathrm{s}$ and $13.09 \mathrm{~cm} / \mathrm{s}$, and $\mathrm{NaCl} 3.5 \%$ solution. FTIR, XRD, Weight loss, Polarization, and Electrochemical Impedance Spectroscopy (EIS) tests were performed to obtain complete information regarding the inhibitor's performance. According to weight loss results at $\mathrm{pH} 5$, the highest efficiency of inhibitor was $82.59 \%$ with 200 ppm inhibitor's concentration, flow rate $7.85 \mathrm{~cm} / \mathrm{s}$, and corrosion rate of $0.104 \mathrm{~mm} / \mathrm{y}$. While at $\mathrm{pH} 7$, the highest efficiency obtained was $92.697 \%$ in $100 \mathrm{ppm}$ concentration of inhibitor, flow rate $7.85 \mathrm{~cm} / \mathrm{s}$, and corrosion rate $0.037 \mathrm{~mm} / \mathrm{y}$. XRD testing showed $\mathrm{Fe}_{24} \mathrm{~N}_{10}$ compound formed as a result of a reaction between Fe and the pyridine nitrogen atom. FTIR testing showed a functional group of inhibitors precipitated on the sample's surface when immersed, and EIS testing showed that the addition of the inhibitor concentration increased the value of polarization resistance of solution, and the value of (constant phase element) decreased. Organic inhibitor becomes alternative protection of corrosion because it is biodegradable, cheap, and also environmentally friendly. The imidazoline inhibitor acts adsorptively on the surface of the AISI 1045 steel by forming the complex Fe24N10 to give a thin film that inhibits the rate of corrosion. Alternative corrosion inhibitors from tobacco can be used or even replace imidazoline inhibitors in applying oil and gas.
\end{abstract}

(C) 2018 The Author(s). Published by TAF Publishing.

\section{INTRODUCTION}

In the oil and gas industry, internal corrosion involving $\mathrm{CO}_{2}$ gas is commonly found. The rate of $\mathrm{CO}_{2}$ corrosion is influenced by several factors, which are $\mathrm{pH}$, temperature, and fluid flow. High $\mathrm{pH}$ environment tends to decrease $\mathrm{CO}_{2}$ corrosion rate. A high $\mathrm{pH}(>4)$ will result in decreasing of $\mathrm{FeCO}_{3}$ solubility and lead to increasing of precipitation rate or scale formation $[1,2]$. The precipitation of $\mathrm{FeCO}_{3}$ finally covers steel surface for further process and yields the decreasing of corrosion rate $[3,4,5]$.

$\mathrm{NaCl}$ concentration in a solution affects the conductivity of solution, which affects the rate of steel corrosion. However, the more concentrated the $\mathrm{NaCl}$, the lesser will be the solubility of reducing agents; hence, the corrosion rate decreases as well. This is due to the saturation of the $\mathrm{NaCl}$ solution resulting in precipitation which creates inability to react in the solution [6].

The effect of fluid flow rate is known to increase mass transport, including corrosion product to move away from steel surface [7]. This yields an exposed surface which makes corrosion process to occur. When protective layer of carbonate iron $\left(\mathrm{FeCO}_{3}\right)$ is formed, or when there are layers due

\footnotetext{
${ }^{*}$ Corresponding author: Mochamad Alvan Mifta Chusururi

†email: mchusururi@gmail.com
} 
to the presence of inhibitors, the effect of the flow rate becomes less significant $[8,9]$.

One of the methods to control corrosion is the usage of inhibitor $[10,11]$. Commercial Imidazoline inhibitor and its derivatives are some of the most effective organic inhibitors to protect metal surfaces from corrosion attacks and have been widely used, in particular to protect $\mathrm{CO}_{2}$ corrosion attacks [12]. Inhibitor-based commercial imidazoline is one of the sulfactant inhibitors of molecules composed of a polar hydrophilic group that is the head of the molecule and there is a non-polar hydrophobic group that is the tail of the molecule $[13,14]$. Sulfactant inhibitors work by physical adsorption or by chemisorption on metal surfaces. The inhibitor molecule contains an amine nitrogen group at the end of the hydrocarbon chain. The active $-\mathrm{NH}_{2}$ group contains unpaired electrons that will be donated to the metal surface. The electron pair of this nitrogen is hydrophilic by replacing the water molecule with the inhibitor molecule $[15,16]$.

The inhibitor tobacco extract inhibitor can be an alternative. Tobacco is a seasonal crop. In Indonesia, many tobacco plants are found. Some areas, such as Temanggung, Bojonegoro, and Jember, are some of the tobacco producing regions. Plants that can be organic inhibitors are plants that have free electron pairs in their constituent atoms, such as nitrite, chromate, phosphate, urea, phenylalanine, and amine compounds. Tobacco is one of the plants that have free electrons which are found in nicotine compounds $[17,18,19]$. The composition of tobacco consists of ash, sugar, phenol, nitrate, and nicotine. The effectiveness of natural material extract as a corrosion inhibitor is due to nitrogen content in tobacco leaf, chemical compounds, such as nicotine, hydrazine, alanine, quinoline, aniline, pyridine, amine, and others [20].

The mechanism of natural material extracts for protection of iron or steel from corrosion attack is estimated to be almost the same as the mechanism of protection by organic inhibitors. In corrosion environments containing $\mathrm{CO}_{2}$ gases, the reaction that occurs between $\mathrm{Fe}^{2+}$ metals and $\mathrm{CO}_{2}$ gas is estimated to produce $\mathrm{FeCO}_{3}$. Further oxidation produces $\mathrm{Fe}_{2}(\mathrm{CO})_{3}$. Inhibitors of nitrogen-containing natural ingredients donate a pair of electrons to the surface of a mild steel metal when the $\mathrm{Fe}^{2+}$ ion diffuses into the electrolyte solution [21].

Nitrogen atoms in nicotine and $\mathrm{Fe}^{2+}$ ions form complex compounds $\left[\mathrm{Fe}\left(\mathrm{NH}_{3}\right)_{6}\right]^{2+}$. This compound has a higher stability than $\mathrm{Fe}^{2+}$; so, it can be used as a protection from corrosion. Then in the imidazoline, derivative-based corrosion inhibitor is a corrosion inhibitor that acts as a mixed corro- sion inhibitor affecting the anodic and cathodic reaction by adsorption process on the metal surface. The mechanism of action of imidazoline-based corrosion inhibitors has 2 nitrogen atoms. The nitrogen atoms in pyridine will donate their electrons to $\mathrm{Fe}^{2+}$ by chemisorption. While the electron pair on a nitrogen atom of Pyrrole is required for the stabilization of the aromatic chains at the head of the imidazoline structure and for forming complex compounds $\mathrm{Fe}_{24} \mathrm{~N}_{10}$ [22].

\section{RESEACRH METHODOLOGY}

\section{A. Inhibitor Preparation}

The inhibitor used for this research was commercial imidazoline inhibitor, with concentrations of $100 \mathrm{ppm}, 150 \mathrm{ppm}$, and $200 \mathrm{ppm}$.

\section{B. Specimen Preparation}

For weight loss, Tafel, and EIS tests, steel AISI 1045 carbon steel was cut to $10 \mathrm{~mm}$ diameter, $10 \mathrm{~mm}$ thick, and drilled $3 \mathrm{~mm}$ at the center of the cylinder. After that, the steel is grinded and polished using sandpaper grade $800-1200$. Prior to immersion, each sample was weighed, measured, and recorded [23].

\section{Solution Preparation}

The solution used was $3.5 \% \mathrm{NaCl}$ solution. $\mathrm{NaCl}$ powder weighed as much as 17.5 grams and then dissolved into a beaker glass to a volume of $500 \mathrm{ml}$.

\section{FTIR Testing}

The purpose of this test is to determine the functional groups present in the imidazoline inhibitors and on the surface of the AISI 1045 steel which has been given immersed in inhibitor solution.

\section{E. Adding Imidazoline Inhibitor in Electrolyte}

Addition of imidazoline inhibitor in $500 \mathrm{ml} \mathrm{NaCl} 3.5 \%$ solution with concentrations $0 \mathrm{ppm}, 100 \mathrm{ppm}, 150 \mathrm{ppm}$, and $200 \mathrm{ppm}$ was done by injecting into beaker glass and then stirring to homogenize solution. After solution got ready, the steel sample was immersed and set flow rate $7.85 \mathrm{~cm} / \mathrm{s}$ and $13.09 \mathrm{~cm} / \mathrm{s}$.

\section{F. Weight Loss Testing}

Testing is done to obtain the value of corrosion rate. After solution got prepared, steel sample was immersed into the solution. The inlet hose and outlet were attached to the lid of the beaker glass. To prevent leakage of gas, plasticine was used to cover the undesired hole on beaker's lid. The inlet 
hose came from $\mathrm{CO}_{2}$ storage. An outlet hose was dipped in the water-filled beaker glass. After that, $\mathrm{CO}_{2}$ gas was delivered into an electrolyte solution for about 15 minutes through an inlet hose. For pH 7, the addition of $7 \mathrm{ml} \mathrm{NaHCO}_{3}$ was performed to obtain desired $\mathrm{pH}$. A dynamo is activated to rotate the specimen with an equivalent flow rate of 7.85 $\mathrm{cm} / \mathrm{s}$ and $13.09 \mathrm{~cm} / \mathrm{s}$. The specimens were immersed for 10 days. Then, we weighed the final weight of the specimen after cleaned from corrosion product. After that, the calculation of corrosion rate and inhibitor efficiency was done [24].

\section{G. Tafel Polarization Testing}

The purpose of this test was to determine the corrosion rate of specimens with the addition of inhibitors and without inhibitors in a short period. The results obtained were Corrosion Potential $\left(\mathrm{E}_{\text {corr }}\right)$, Current Density ( $\left.\mathrm{i}_{\text {corr }}\right)$, and corrosion rate. This test was performed to certain samples, which were for imidazoline inhibitors, at pH 5, 0 ppm, and 200 ppm inhibitor and at pH 7, 0 ppm, and 100 ppm inhibitor.

\section{H. EIS Testing}

EIS testing is a method to obtain the inhibition mechanism of imidazoline extract and resistance to corrosion caused by the addition of inhibitor of imidazoline on the surface of AISI 1045 steel [25]. This test was performed on sample at $\mathrm{pH}$ 5, $0 \mathrm{ppm}$, and $200 \mathrm{ppm}$ inhibitor and at $\mathrm{pH}$ 7, $0 \mathrm{ppm}$, and 100 ppm inhibitor.

\section{XRD Testing}

This test was performed to determine the compounds precipitated on the steel surface after immersion into solution with inhibitor after 10 days.

\section{DATA ANALYSIS}

\section{A. Weight Loss Testing Result}

To obtain corrosion rate and the efficiency of inhibitor, the following equation is used:

$$
\begin{gathered}
C R=\frac{k \cdot w}{D \cdot A \cdot T} \\
\% E I=\frac{C R O-C R 1}{C R O} \times 100 \%
\end{gathered}
$$

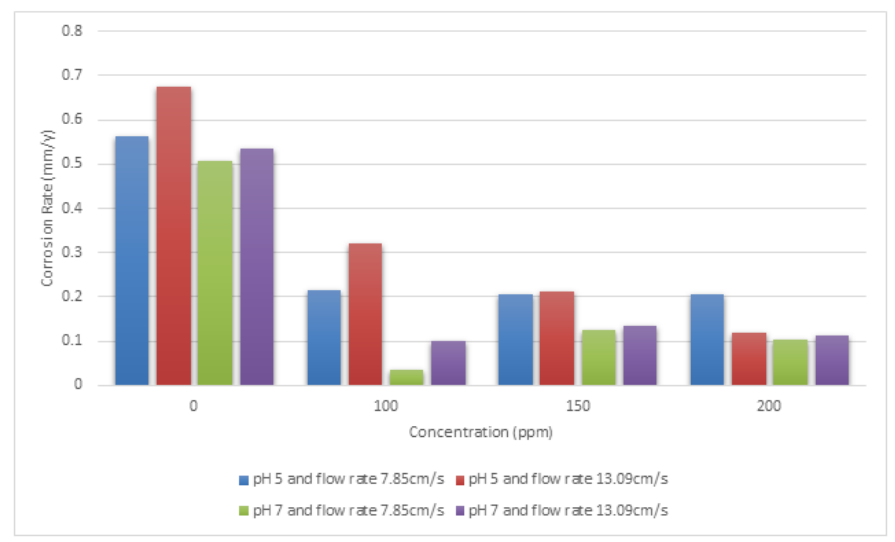

Fig. 1. Corrosion rate of AISI 1045 samples in 3.5\% $\mathrm{NaCl}$ at various $\mathrm{pH}$, inhibitor concentrations, and flow rates

Figure 1 shows the effect of imidazoline inhibitor concentration on the corrosion rate of AISI 1045 steel at pH 5 and $\mathrm{pH} 7$, with flow rates of $7.85 \mathrm{~cm} / \mathrm{s}$ and $13.09 \mathrm{~cm} / \mathrm{s}$. Based on the result, it was found that the increasing of inhibitor concentration decreased the corrosion rate of AISI 1045 steel. At pH 5, the lowest corrosion rate was obtained at 200ppm inhibitor concentration and a flow rate of $13.09 \mathrm{~cm} / \mathrm{s}$ which is $0.118 \mathrm{~mm} /$ year. While at $\mathrm{pH} 7$, the lowest corrosion rate was obtained at $100 \mathrm{ppm}$ inhibitor concentration of 0.037 $\mathrm{mm} /$ year at $7.85 \mathrm{~cm} / \mathrm{s}$. However, at concentration of 150 $\mathrm{ppm}$, the corrosion rate increased, then decreased again at a concentration of $200 \mathrm{ppm}$.
Figure 2 shows the effect of imidazoline inhibitor concentration on the inhibitor efficiency of AISI 1045 steel at $\mathrm{pH}$ 5 and pH 7, with flow rates of $7.85 \mathrm{~cm} / \mathrm{s}$ and $13.09 \mathrm{~cm} / \mathrm{s}$. According to the Figure 2, the increasing concentration of inhibitors increases the efficiency of imidazoline corrosion inhibitors. The highest efficiency obtained at $\mathrm{pH} 5$ was $82.59 \%$ at $200 \mathrm{ppm}$ inhibitor and flow rate $13.09 \mathrm{~cm} / \mathrm{s}$. While at $\mathrm{pH} 7$, the highest inhibitor efficiency was $63.573 \%$ 


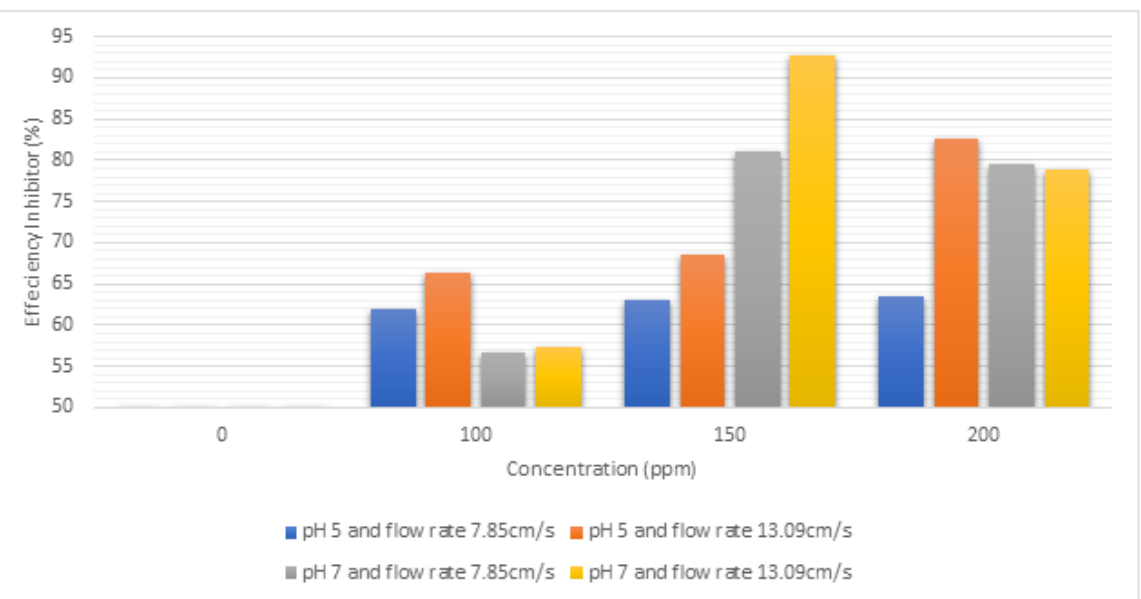

Fig. 2. Inhibitor efficiency of AISI 1045 samples in 3.5\% $\mathrm{NaCl}$ at various $\mathrm{pH}$, inhibitor concentrations, and flow rates

at flow rate $7.85 \mathrm{~cm} / \mathrm{s}$. Based on the result, it is found that the increasing inhibitor concentration increases the efficiency of imidazoline corrosion inhibitor.

\section{B. Polarization (Tafel) Test Results}

Tafel test was performed on samples having the highest and lowest corrosion rates at each $\mathrm{pH}$. There are two samples for polarization testing. At $\mathrm{pH}$, the sample used had concentrations of $0 \mathrm{ppm}$ and $200 \mathrm{ppm}$ with a flow rate of 13.09 $\mathrm{cm} / \mathrm{s}$. And at $\mathrm{pH} \mathrm{7,} \mathrm{the} \mathrm{samples} \mathrm{used} \mathrm{were} \mathrm{with} \mathrm{inhibitor}$ concentrations of $0 \mathrm{ppm}$ and $100 \mathrm{ppm}$ at a flow rate of 7.85 $\mathrm{cm} / \mathrm{s}$. The results are shown in figure below:

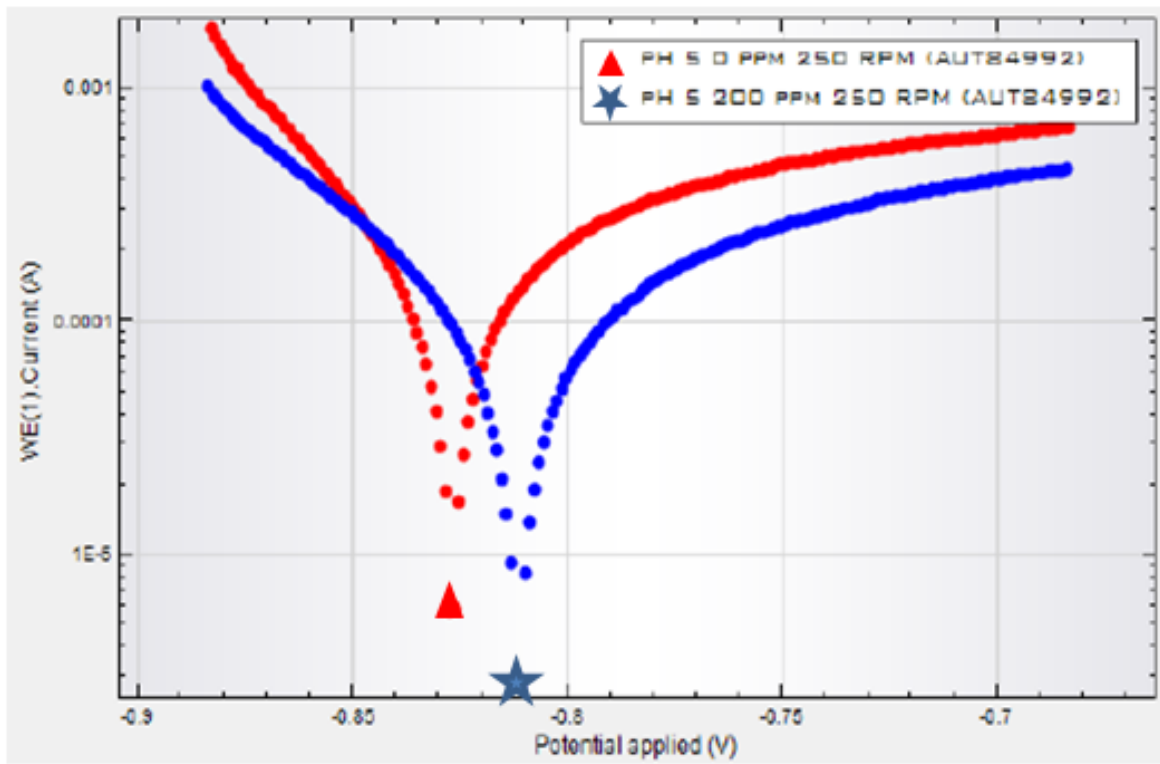

Fig. 3. Polarization curve of AISI 1045 steel in $3.5 \% \mathrm{NaCl}$ with $\mathrm{CO}_{2}$ environment at $\mathrm{pH} 5$ with $0 \mathrm{ppm}$ and $200 \mathrm{ppm}$ imidazoline inhibitor

TABLE 1 RESULTS OF IMIDAZOLINE INHIBITOR TAFEL ANALYSIS AT PH 5, FLOW RATE 13.09 CM/S

\begin{tabular}{ccccccc}
\hline \hline $\mathrm{pH}$ & $\begin{array}{c}\text { Concentration } \\
(\mathrm{ppm})\end{array}$ & $\begin{array}{c}\text { Flow Rate } \\
\mathrm{cm} / \mathrm{s}\end{array}$ & $\begin{array}{c}\mathrm{E}_{\text {corr }} \\
(\mathrm{mV})\end{array}$ & $\begin{array}{c}\mathrm{i}_{\text {corr }} \\
(\mu \mathrm{A} / \mathrm{cm} 2)\end{array}$ & $\begin{array}{c}\mathrm{Cr} \\
(\mathrm{mm} / \mathrm{y})\end{array}$ & Inhibitor Efficiency (\%) \\
\hline 5 & 0 & 13.09 & -826.82 & 56.8111 & 0.66 & - \\
& 200 & & -811.98 & 20.196 & 0.234 & 64.45 \\
\hline \hline
\end{tabular}


Figure 3 shows that with increasing imidazoline inhibitor concentration, it shifts the tafel curve downward. The downward shifting of the tafel curve with the corrosion inhibitor indicates the decrease of icorr value so that the corrosion rate decreases. The shift of the tafel curve towards right or more positive after the corrosion inhibitor is given shows the electrochemical reaction that occurs between the electrolyte solution, and the test sample becomes more anodic. This means that the reaction on steel sample is more dominant when compared with the reaction in the solution.

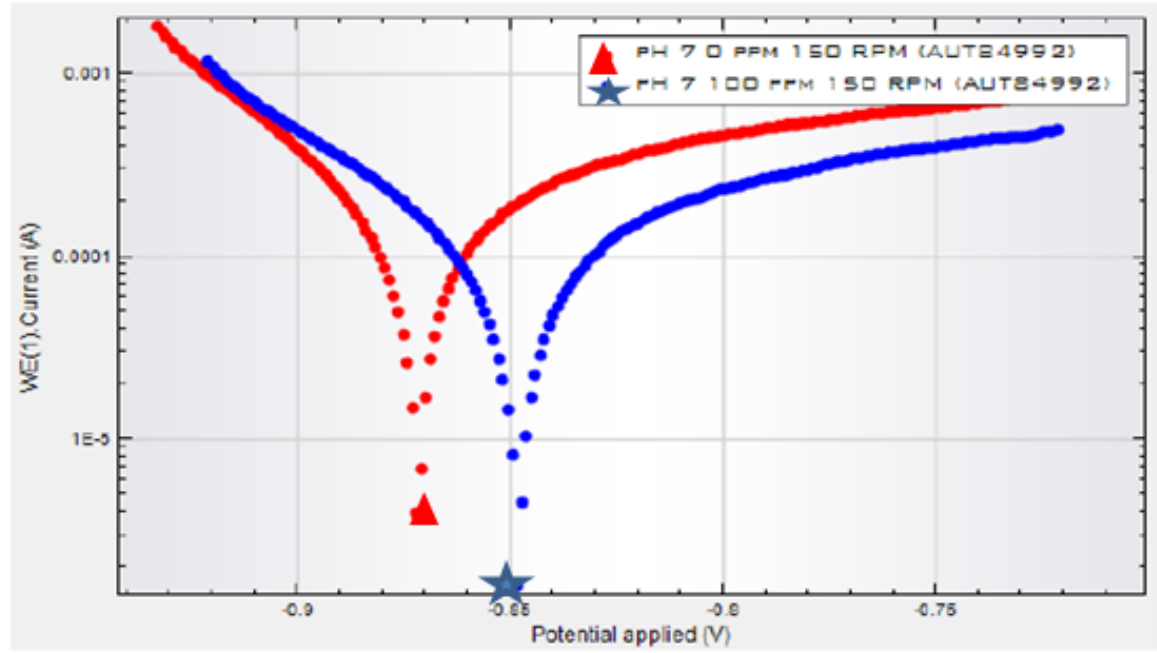

Fig. 4. AISI 1045 Steel Polarization Curve in $3.5 \% \mathrm{NaCl}$ with $\mathrm{CO}_{2}$ environment at $\mathrm{pH} 7$ with 0 ppm and $100 \mathrm{ppm}$ imidazoline inhibitor

TABLE 2

RESULTS OF IMIDAZOLINE INHIBITOR TAFEL ANALYSIS AT PH 7, FLOW RATE 7.85

\begin{tabular}{ccccccc}
\hline \hline $\mathrm{pH}$ & $\begin{array}{c}\text { Concentration } \\
(\mathrm{ppm})\end{array}$ & $\begin{array}{c}\text { Flow Rate } \\
\mathrm{cm} / \mathrm{s}\end{array}$ & $\begin{array}{c}\mathrm{E}_{\text {corr }} \\
(\mathrm{mV})\end{array}$ & $\begin{array}{c}\mathrm{i}_{\text {corr }} \\
(\mu \mathrm{A} / \mathrm{cm} 2)\end{array}$ & $\begin{array}{c}\mathrm{Cr} \\
(\mathrm{mm} / \mathrm{y})\end{array}$ & \begin{tabular}{c} 
Inhibitor Efficiency (\%) \\
\hline 7
\end{tabular} \\
0 & 7.85 & -871.94 & 36.592 & 0.425 & - \\
& 100 & & -848.39 & 9.3936 & 0.109 & 74.3295 \\
\hline \hline
\end{tabular}

Figure 4 shows that an increasing of imidazoline inhibitor concentration is followed by shifting the tafel curve downward. It indicates the decrease of icorr value so that the corrosion rate decreases. The shift of the tafel curve towards right or more positive after the corrosion inhibitor is given shows the electrochemical reaction that occurs between the electrolyte solution, and the test sample becomes more anodic. This means that the reaction in the test sample is more dominant when compared with the reaction in the solution. And Table 2 shows the addition of inhibitor will lower the $\mathrm{i}_{\text {corr. }}$.

According to Figure 5 above, at 200 ppm imidazoline inhibitor at $\mathrm{pH} 5$, the duration of immersion process affects corrosion behaviour of steel sample. It appears to decrease the corrosion rate. On the first day, the corrosion rate was $0.234 \mathrm{~mm} / \mathrm{y}$ and decreased to $0.118 \mathrm{~mm} / \mathrm{y}$ on day 10 . At pH 7 and 100ppm imidazoline inhibitor, similar tendency is found; the longer immersion process was followed by decreasing corrosion rate. On the first day, the corrosion rate was $0.109 \mathrm{~mm} / \mathrm{y}$ and on day 10 , the corrosion rate decreased to $0.037 \mathrm{~mm} / \mathrm{y}$.

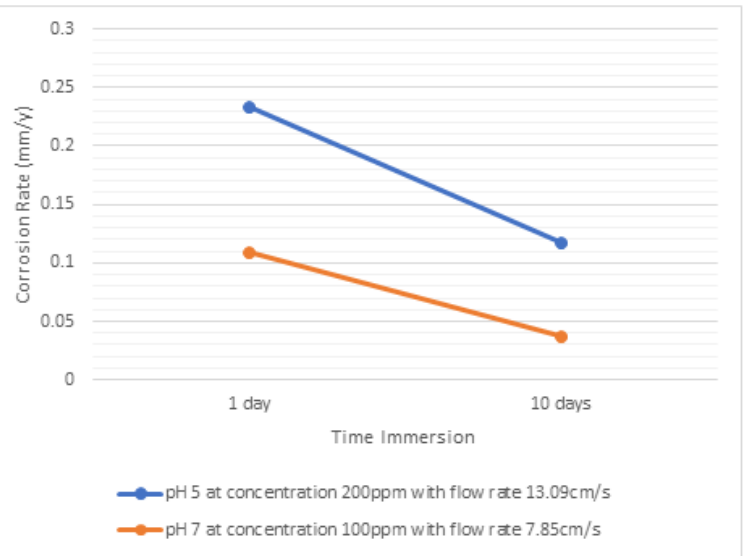

Fig. 5. Corrosion rate and time on AISI 1045 of imidazoline inhibitor in $3.5 \% \mathrm{NaCl}$ at various $\mathrm{pH}$, various concentrations, and various flow rates 


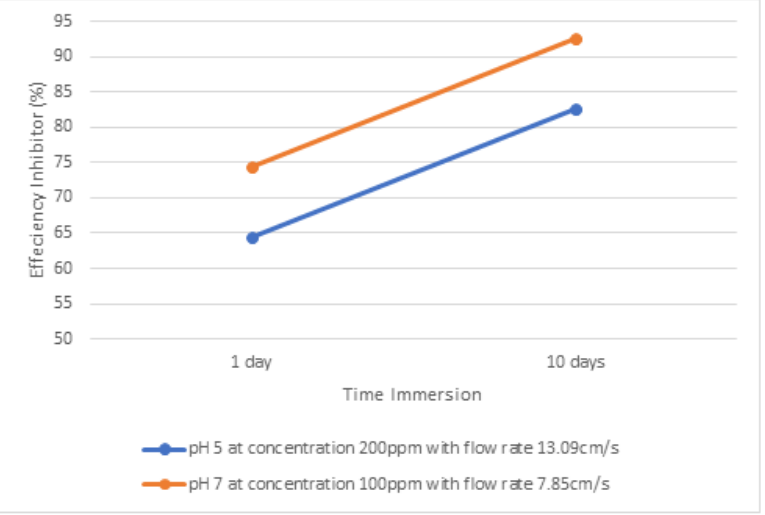

Fig. 6. Efficiency and time on AISI 1045 of imidazoline inhibitor in $3.5 \% \mathrm{NaCl}$ at various $\mathrm{pH}$, various concentrations, and various flow rates

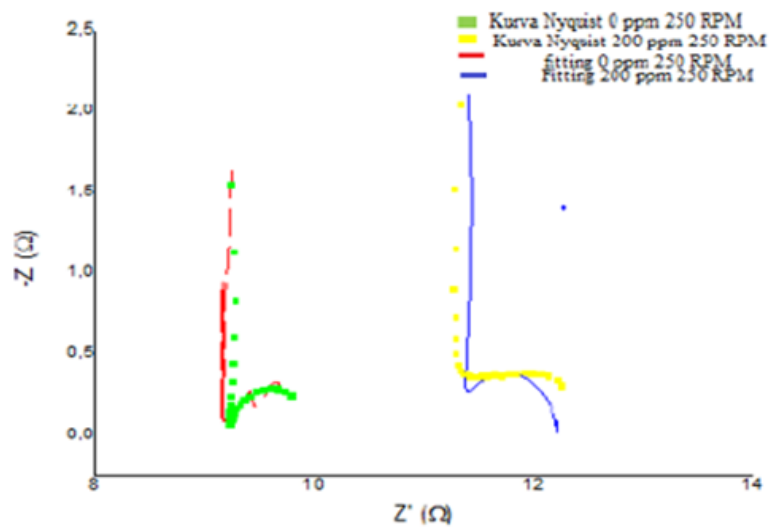

Fig. 7. Nyquist curve and fitting on sample at pH 5 with inhibitor imidazoline concentrations 0 ppm and 200 ppm

In Figure 6 with a concentration of 200 ppm imidazoline inhibitor at $\mathrm{pH} 5$, the longer immersion process appears to increase the efficiency of the inhibitor. On the first day, $64.4550 \%$ efficiency continues to increase until day 10 with an efficiency of $82.59 \%$. Then with a concentration of 100 ppm imidazoline inhibitor at $\mathrm{pH} 7$, the longer immersion process appears to increase the efficiency of the inhibitor.
On the first day, the efficiency of $74.33 \%$ continues to increase until day 10 with an efficiency of $92.69 \%$.

\section{EIS Test Results}

At the time of EIS testing, Nyquist curve was obtained from NOVA software. The Nyquist curve was fitted and plotted to produce electrochemical parameters of R-Resistor, CCapacitor, and Constant Phase Element (CPE).

The test results in the form of Nyquist curve show the result of electrical circuit which begins with the Resistance of the Solution (RS), where the resistance value is generated by the solution between the auxiliary electrode and the working electrode, then followed by the Polarization Resistance (Rp) and CPE. The circuit continued with Rp and CPE for the second time, where $\mathrm{Rp}$ describes the polarization resistance that occurs when metal interface interacts with electrolyte solution and dissolution of ions occurs. The value of $\mathrm{Rp}$ in the first circuit has a value greater than the second Rp value, causing the first Rp to cause a significant decrease in corrosion rate. Then at the second $\mathrm{Rp}$, the value of corrosion rate tends to increase because the value of Rp tends to be small. The CPE is used as a Double Layer Capacitance (DLC) model to compensate for surface non-homogeneity. Rough or porous metal surfaces may cause double layer capacitance DLC to be present as CPE [26]. The value of CPE also indicates a reduction in value with the addition of corrosion inhibitors. This shows that there is a passive layer that forms on the metal surface and removes the electrolyte attached to the metal surface [27].

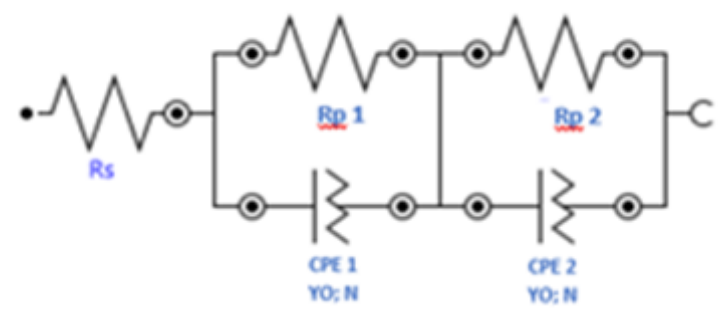

Fig. 8. Electrical circuit model of EIS test result

TABLE 3

EQUIVALENT CIRCUIT DATA OF IMIDAZOLINE INHIBITOR SAMPLE AT PH 5

\begin{tabular}{lccccccccc}
\hline $\begin{array}{l}\text { Concentration } \\
(\mathrm{ppm})\end{array}$ & $\mathrm{pH}$ & $\begin{array}{c}\text { Flow Rate } \\
(\mathrm{cm} / \mathrm{s})\end{array}$ & $\begin{array}{c}\mathrm{Rs} \\
(\mathrm{m} \Omega)\end{array}$ & $\begin{array}{c}\mathrm{Rp} 1 \\
(\mathrm{~m} \Omega)\end{array}$ & $\begin{array}{c}\mathrm{Rp} 2 \\
(\mathrm{~m} \Omega)\end{array}$ & $\begin{array}{c}\text { CPE 1 } \\
\text { Y0 (nMo) }\end{array}$ & $\begin{array}{c}\mathrm{N} \\
\text { Y0 (mMho) }\end{array}$ & $\begin{array}{c}\text { CPE 2 } \\
\text { (mM }\end{array}$ \\
\hline 0 & 5 & 13.09 & -18.5 & 11.4 & 0.79 & 12.5 & 1.1 & 20.3 & 0.8 \\
200 & & & -12.9 & 18.0 & 0.91 & 6.76 & 1.1 & 1.1 & 0.86 \\
\hline \hline
\end{tabular}

In Figure 7, an increase in diameter of the Nyquist curve is shown with increase in inhibitor concentration. According to [28], an increase in the diameter of the Nyquist curve sig- nifies an increase in resistance. From Table 2, it can be seen that the value of the RS in solution of $\mathrm{pH} 5$ has increased from $-18.5 \Omega$ to $-12.9 \Omega$ with the addition of $200 \mathrm{ppm}$ in- 
hibitor. Then, the value of Rp has increased with the addition of $200 \mathrm{ppm}$ inhibitor. The $\mathrm{Rp}$ value is proportional to the value of the Charge Transfer Resistance (Rct). The Rct represents the displacement of the charge on the interface between the metal and the solution. The value of CDL in the circuit appears as CPE was caused by an uneven surface or rough [29]. The results of CPE values indicate a reduction in value with the addition of corrosion inhibitors. This shows that there is a passive layer that forms on the metal surface and removes the electrolyte attached to the metal surface [27].

In Figure 9, there is an increase in diameter of Nyquist curve with the increase in inhibitor concentration. In Table 4, it is known that the value of the resistivity of the solution (Rs) in solution of $\mathrm{pH} 7$ has decreased from $-5.57 \Omega$ to $-18.7 \Omega$ with the addition of $100 \mathrm{ppm}$ inhibitor. The value of polarization resistance (Rp) increases with the addition of $100 \mathrm{ppm}$ inhibitor. The value of CPE also indicates a reduction in value with the addition of corrosion inhibitors. This shows that there is a passive layer that forms on the metal surface and removes the electrolyte attached to the metal surface [27].

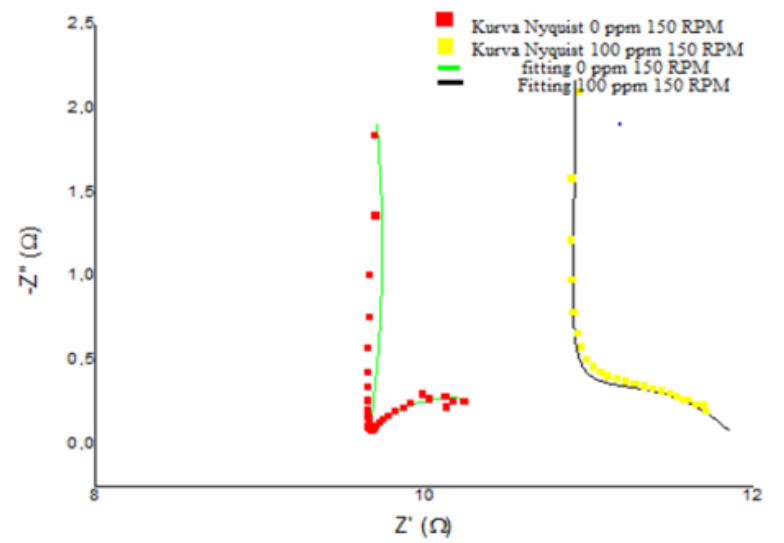

Fig. 9. Nyquist curve and fitting of sample at $\mathrm{pH} 7$ with concentrations of Imidazoline inhibitor 0 and $200 \mathrm{ppm}$

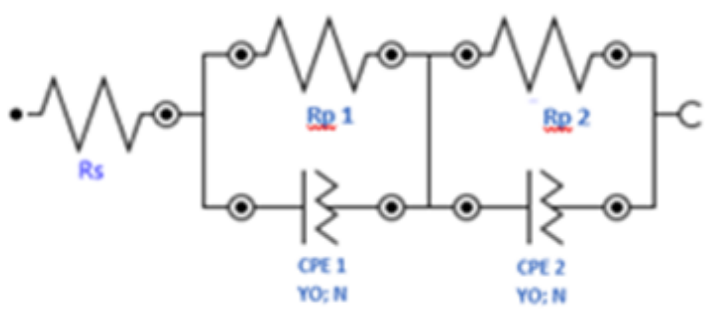

Fig. 10. Electrical Circuit Model of EIS Test Result

TABLE 4

EQUIVALENT CIRCUIT DATA OF IMIDAZOLINE INHIBITOR SAMPLE AT PH 7

\begin{tabular}{lccccccccc}
\hline \hline $\begin{array}{l}\text { Concentration } \\
(\mathrm{ppm})\end{array}$ & $\mathrm{pH}$ & $\begin{array}{c}\text { Flow Rate } \\
(\mathrm{cm} / \mathrm{s})\end{array}$ & $\begin{array}{c}\mathrm{Rs} \\
(\mathrm{m} \Omega)\end{array}$ & $\begin{array}{c}\mathrm{Rp} 1 \\
(\mathrm{~m} \Omega)\end{array}$ & $\begin{array}{c}\text { Rp 2 } \\
(\mathrm{m} \Omega)\end{array}$ & $\begin{array}{c}\text { CPE 1 } \\
\text { Y0 (nMho) }\end{array}$ & $\begin{array}{c}\text { CPE 2 } \\
\text { Y0 (mMho) }\end{array}$ & $\mathrm{N}$ \\
\hline 0 & 7 & 7.85 & -5.57 & 15.2 & 0.96 & 8.6 & 1.1 & 38 & 0.68 \\
100 & & & -18.7 & 29.4 & 1.29 & 2.53 & 1.1 & 5.85 & 0.56 \\
\hline \hline
\end{tabular}

\section{XRD Test Result}

XRD (X-Ray Diffraction) testing was performed on specimens that have been immersed with a concentration of 200 ppm imidazoline inhibitor at $\mathrm{pH} 7$ and a flow rate of 7.85 $\mathrm{cm} / \mathrm{s}$. The XRD results in the sample were matched based on the highest peak that appeared. From the XRD test results, the highest peak position is the $\mathrm{Fe}_{24} \mathrm{~N}_{10}$ compound in figure 11 corresponding to ICDD 01-073-2103.

\section{E. FTIR Test Results}

From the FTIR analysis, there are several functional groups corresponding to the molecular structure of the imidazoline inhibitor in Figure 12.

The functional groups are amine $(\mathrm{NH})$, aromatic rings $(\mathrm{C}=$ $\mathrm{N}$ ), aromatics (C strech in ring), and aromatic amines (CN). For FTIR, test results on AISI 1045 steel samples which have been soaked for 10 days with the addition of 200 ppm inhibitor concentration and flow rate at $\mathrm{pH} 7$ are in the same picture. From the FTIR analysis, there are several functional groups similar to those of FTIR testing on imidazoline inhibitors. The functional groups are Amines $(\mathrm{N}-\mathrm{H})$ and Alkanes (C-H). In a study conducted by [30], there was an $\mathrm{N}-\mathrm{H}$ functional group on the test sample. In the presence of an amine functional group on the steel surface, the imidazoline corrosion inhibitor acts to protect the metal surface from corrosion.

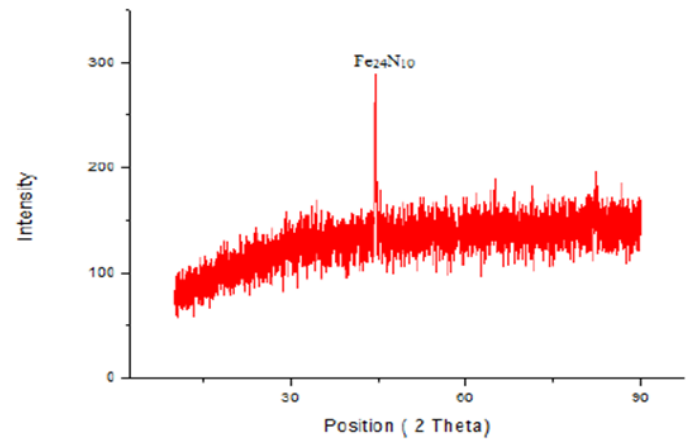

Fig. 11. XRD test result of imidazoline inhibitor 


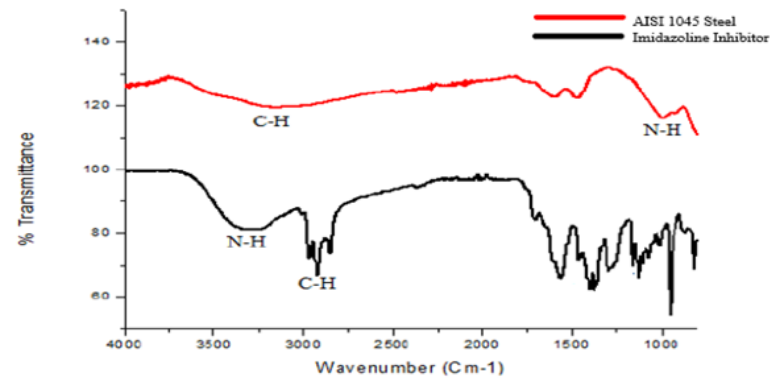

Fig. 12. FTIR results comparison of imidazoline inhibitor substance and AISI 1045 steel samples

\section{F Langmuir Adsorption Isotherm Theory}

The theory of Langmuir adsorption isotherm is used to identify the interaction between the inhibitors and the steel surface. Using the calculations from Langmuir's theory, it can be indicated what kind of adsorption is occurring on the surface of the steel. The calculation on the Langmuir adsorption isotherm uses the equation below [31].

$$
\theta=\frac{I E \%}{100}
$$

$$
\begin{gathered}
K a d s=\frac{\theta}{c(1-\theta)} \\
\Delta G^{0}=\operatorname{RTIn}(55.5 \times \text { Kads })
\end{gathered}
$$

Where $\theta$ is surface coverage, \%EI is efficiency inhibitor, $\mathrm{C}$ is concentration, $\mathrm{R}$ is gas constant $(0.008314 \mathrm{kj} / \mathrm{molK})$ and $\mathrm{T}$ is temperature $\left({ }^{0} \mathrm{~K}\right)$. The calculation results show the value of $\Delta$ Gads in imidazoline inhibitors with each addition of inhibitor concentration. The full adsorption-free energy value can be seen in Table 5. Then for the $\mathrm{CO}_{2}$ environment in $\mathrm{NaCl} \mathrm{pH} 7$ were identified that the interaction between inhibitors and steel surfaces in similar to $\mathrm{pH} 5$.

Based on the value of $\Delta$ Gads the adsorption method on the steel surface can be known. If the value of $\Delta$ Gads is more positive than $-20 \mathrm{kj} / \mathrm{mol}$ then the adsorption process formed is physiorption. If $\Delta$ Gads value is between -20 and -40 then the adsorption process is a mixed process of physiorption and chemisorption. While the process of chemisorption occurs when the value of $\Delta$ Gads is more negative than $-40 \mathrm{kj} / \mathrm{mol}$.

TABLE 5

ADSORPTION FREE ENERGY DATA IMIDAZOLINE INHIBITOR

\begin{tabular}{cccccc}
\hline \hline $\mathrm{pH}$ & $\begin{array}{c}\text { Concentration Inhibitor } \\
(\mathrm{ppm})\end{array}$ & $\begin{array}{c}\text { Flow rate } \\
(\mathrm{cm} / \mathrm{s})\end{array}$ & $\begin{array}{c}\text { Surface Coverage } \\
(\theta)\end{array}$ & $\mathrm{K}_{\mathrm{ads}}$ & $\begin{array}{c}\Delta \text { Gads } \\
(\mathrm{Kj} / \mathrm{mol})\end{array}$ \\
\hline 5 & 0 & 13.09 & 0 & 0 & 0 \\
& 200 & & 0.6445 & 0.009065 & 1.70205 \\
7 & 0 & 7.85 & 0 & 0 & 0 \\
& 100 & & 0.743295 & 0.02895 & 1.175306 \\
\hline \hline
\end{tabular}

From Table 5 the adsorption free energy value at $\mathrm{pH} 5$ with concentration of $200 \mathrm{ppm}$ and flow rate of $13.09 \mathrm{~cm} / \mathrm{s}$ is $-1,70205 \mathrm{Kj} / \mathrm{mol}$ and the adsorption free energy at $\mathrm{pH} 7$ with concentration of $100 \mathrm{ppm}$ and flow rate of $7.85 \mathrm{~cm} / \mathrm{s}$ is $1,175306 \mathrm{Kj} / \mathrm{mol}$. According to [32], if the value of $\Delta \mathrm{G}$ is more positive than $-20 \mathrm{kj} / \mathrm{mol}$ then the adsorption process is physiorption.

\section{DISCUSSION}

In imidazoline inhibitor Figure 1. There are phenomenon increasing and decreasing efficiency when inhibitor imidazoline present, This is exceed Critical Micelle Concentration (CMC). Thus, the addition of sulfactant inhibitors to the solution above CMC will form micelles or multiple layers adsorbed on the metal surface. Consequently, the surface tension and corrosion flow density does not change significantly above the CMC [33], due to the addition of $\mathrm{pH}$ from the results of testing the decreased corrosion rate of the sample. This occurs because an increase in $\mathrm{pH}$ of more than 4 decreases $\mathrm{FeCO}_{3}$ solubility, leading to an increase in the precipitation rate of $\mathrm{FeCO}_{3}$. Thus, the surface area of steel in direct contact with the electrolyte will be reduced. This causes a decrease in the rate of corrosion When compared with Tobacco inhibitor reserch by [20] optimal performance is $86.51 \%$ at $\mathrm{pH} 7$ with concentration $132.5 \mathrm{ppm}$ and the flow rate is $7.85 \mathrm{~cm} / \mathrm{s}$, while in $\mathrm{pH} 4$ show the efficiency inhibition from tobacco extract is $74.69 \%$ with concentration $265 \mathrm{ppm}$. It is possible that toccaco inhibitors have a low efficiency compared to imidozoline inhibitors Figure 1 and Figure 2, in terms of results for both still include a good inhibitor. but it is still possible if the tobacco inhibitor is tested at $\mathrm{pH} 5$ the inhibition efficiency will be greater than that of the imidazoline inhibitor at the same $\mathrm{pH}$. This is because at $\mathrm{pH} 4$ reduction reaction of $\mathrm{H}+$ ions tend to be dominant, the ion reduction reaction of $\mathrm{H}+$ dominates in the cathodic reaction in the corrosion process. 
Reduction of $\mathrm{H}+$ ions are more sensitive than $\mathrm{H}_{2} \mathrm{CO}_{3}$ reduction causing the corrosion rate to be more sensitive to occur at low $\mathrm{pH}(\mathrm{pH}<4)$. While at above $\mathrm{pH} 4$ the corrosion rate tends to decrease due to the depletion of $\mathrm{H}+$ ions required for cathodic reactions in $\mathrm{CO}_{2}$ corrosion [3].

Flow rate of fluid affect at the corrosion behavior of steelThe greater the value of wall shear stress, the greater the scour in the layers of corrosion products and thin films due to the addition of inhibitors that have been formed. Thus, it will increase the corrosion rate on the metal surface [34, 35]. on the results of FTIR samples of imidazoline inhibitors there are several functional groups such as $\mathrm{N}-\mathrm{H}, \mathrm{C}-\mathrm{H}, \mathrm{C}=$ $\mathrm{N}, \mathrm{C}-\mathrm{N}$. The presence of an amine functional group $(\mathrm{N}-\mathrm{H})$ present at the head of the imidazoline molecular structure, indicating the presence of an electron donor provided by the nitrogen atom in the pyrine to Fe of the test sample. Thus, a strong reaction exists between the imidazoline inhibitor and the test sample and a passive layer that protects the metal from corrosion [22]. The presence of a C-H bond as a branch chain indicates the presence of a hydrocarbon group on the metal surface. With the presence of this $\mathrm{C}-\mathrm{H}$ group, making imidazoline compounds have the ability to hydrophobic or reject water molecules [30]. And with result reserch of [20] tobacco inhibitor samples there are functional groups $\mathrm{C}=\mathrm{N}$ (oximes) and $\mathrm{C}-\mathrm{H}$ (ketones) which are included in the functional group portion of nicotine. Where the molecular formula of nicotine itself is $\mathrm{C}_{10} \mathrm{H}_{14} \mathrm{~N}_{2}$ which has functional groups $\mathrm{C}=\mathrm{N}$ and $\mathrm{C}-\mathrm{H}$. Content of nicotine in tobacco extract is able to inhibit the rate of corrosion by donating nitrogen atoms on nicotine to $\mathrm{Fe}^{2+}$ to form ion ion [Fe $\left.\left(\mathrm{NH}_{3}\right)_{6}\right]^{2+}$ This complex ion has a higher stability than Fe so it can be used as a protection in corrosion. In FTIR testing with specimens that had undergone immersion with tobacco extract inhibitor the functional group $\mathrm{C}=\mathrm{N}$ were found. In addition, there is also a functional group of N-H in which the functional group is one of the groups composing the complex of $\left[\mathrm{Fe}\left(\mathrm{NH}_{3}\right)_{6}\right]^{2+}$ So, through the FTIR results it can be known that one of the mechanisms that occur in imidazoline and tobacco inhibitors is by forming complex compounds on the steel surface.

For polarization testing Figure 3 and Figure 4, result prove that the decrease of icorr on the addition inhibitor. With the decreasing of icorr value indicates that the resistance which inhibits the transfer of charge both from the cathode and anode side due to adsorption of the inhibitor on metal surface [35]. The shifting of the tafel curve towards the right after the corrosion inhibitor is given shows the electrochemical reaction that occurs between the electrolyte solution and the test sample becomes more anodic $[36,37]$. So, the re- action in the test sample is more dominant when compared with the reaction in the solution. it is same with result of tobbaco inhibitor [20].

And for EIS testing for both inhibitors is that the addition of an inhibitor increases the value of polarization resistance (Rp). The resistance represents the displacement of the charge on the interface between the metal and the solution. With an increase in the resistance value, it indicates the existence of a passive layer formed on the metal surface. Thus, the movement of ions from the metal to the electrolyte becomes obstructed. From the results of CPE values indicate a reduction in value with the addition of corrosion inhibitors. This shows that there is a passive layer that forms on the metal surface and removes the electrolyte attached to the metal surface [27].

In the calculation of the adsorption-free energies of $\Delta$ Gads to find out the type of adsorption occurring between the metal surfaces and the corrosion inhibitor, it was found that all the calculations showed that the type of adsorption that occurred between the corrosion inhibitor and the metal surface was physical adsorption. Due to the value of $\Delta$ Gads is high than $-20 \mathrm{kj} / \mathrm{mol}$. However, from the results of FTIR testing, XRD showed that the mechanism of inhibition of corrosion inhibitor imidazoline is Chemisorption. From [20] tobacco inhibitor has same mechanism that was physisorption because $-2,44854 \mathrm{kj} / \mathrm{mol}$ dan $1,192738 \mathrm{~kJ} / \mathrm{mol}$ in $\mathrm{pH} 4$ and $\mathrm{pH} 7$.

The mechanism of action of imidazoline-based corrosion inhibitors is from the molecular structure of on the head, having 2 nitrogen atoms. The nitrogen atoms in pyridine will donate their electrons to Fe by chemisorption. While the electron pair on a nitrogen atom of Pyrrole, it is required for the stabilization of the aromatic chains of the head group of the imidazoline structure [22]. Then the non-polar hydrocarbon tail of this inhibitor molecule lies vertically to the metal surface. The molecular hydrocarbon chain of these inhibitors intercepts to each other a closed netlike layer that will reject the liquid phase due to the nature of the hydrophobic character [38].

It can be seen that the longer immersion process decreases the corrosion rate, it indicated by the formation of barrier of $\mathrm{Fe}_{24} \mathrm{~N}_{10}$ layer formation, and at flow rate besides causing erosion corrosion also helps the interaction rate between inhibitor and metal surface so that corrosion rate is slower compared to the formation of barrier layers that block the interaction of surface metals and electrolytes. with the same explanation in $\mathrm{pH} 4$ and $\mathrm{pH} 7$ the results obtained from complex compounds of tobacco were Fe $\left.\left(\mathrm{NH}_{3}\right)_{6}\right]^{2+}[20]$. From all tests performed to determine the effect of $\mathrm{pH}$, 
flow rate and imidazoline concentration on corrosion rate on AISI 1045 steel, it was found that in the presence of increased inhibitor concentration and $\mathrm{pH}$ of the solution will decreased the corrosion rate of AISI 1045 steel. However, the increasing flow rate caused the rate of corrosion to increased again at the same $\mathrm{pH}$ and concentration inhibitors. Tobacco inhibitor [20] also can decrease the corrosion rate in the same flow rate and condition but in $\mathrm{pH} 4$ and pH 7 was more aggressive than imidazoline inhibitor.

\section{A. For Imidazoline Inhibitor}

\section{CONCLUSION}

The addition of imidazoline corrosion inhibitor can decreased corrosion rate. at the lowest corrosion rate in $\mathrm{pH}$ 7 and flow rate of $7.85 \mathrm{~cm} / \mathrm{s}$ at $100 \mathrm{ppm}$ inhibitor concentration of $0.037 \mathrm{~mm} / \mathrm{y}$ and efficiency $92.697 \%$. However,
Imidazoline inhibitors can also work at $\mathrm{pH} 5$, the lowest corrosion rate is obtained at a concentration of $200 \mathrm{ppm}$ with a corrosion rate of $0.118 \mathrm{~mm} / \mathrm{y}$ and an efficiency of $82.597 \%$. The phenomena increasing and decreasing efficiency to concentration due to exceed CMC.

The imidazoline inhibitor acts adsorptively on the surface of the AISI 1045 steel by forming the complex $\mathrm{Fe}_{24} \mathrm{~N}_{10}$ to give a thin film which inhibits the rate of corrosion.

Alternative corrosion inhibitor from tobacco can be used or even replace imidazoline imhibitor on applying oil and gas industry.

\section{ACKNOWLEDGEMENT}

Thank you to MANDIRI BANK for funding the conference's departure at the 4th International Conference on "Global Issues in Multidisciplinary Academic Research" (GIMAR2018) (C) 2018 Global Illuminators, Tokyo, Japan.

\section{REFERENCES}

[1] N. N. M. FirdausHum and S. A. Talib, "Spatial interpolation of monthly precipitation in selangor, Malaysia-comparison and evaluation of methods," Journal of Applied and Physical Sciences, vol. 2, no. 1, pp. 1-9, 2016. doi: 10.20474/-japs2. 1.1

[2] L. Moiseeva and N. Rashevskaya, "Effect of $\mathrm{pH}$ value on corrosion behavior of steel in $\mathrm{CO}_{2}$-containing aqueous media," Russian Journal of Applied Chemistry, vol. 75, no. 10, pp. 1625-1633, 2002.

[3] I. S. P. Dewi, Effect of pH Variation and Acetic Acid Concentration on $\mathrm{CO}_{2}$ Characteristics on steel BS 970. Surabaya, Indonesia: Sepuluh Institute of Technology Press, 2012.

[4] S. Nešic and K.-L. Lee, "A mechanistic model for carbon dioxide corrosion of mild steel in the presence of protective iron carbonate films-part 3: Film growth model," Corrosion, vol. 59, no. 7, pp. 616-628, 2003. doi: 10.5006/1.3277592

[5] D. L. Tomasko, H. Li, D. Liu, X. Han, M. J. Wingert, L. J. Lee, and K. W. Koelling, “A review of $\mathrm{CO}_{2}$ applications in the processing of polymers," Industrial \& Engineering Chemistry Research, vol. 42, no. 25, pp. 6431-6456, 2003.

[6] F. Liu, M. Du, J. Zhang, and M. Qiu, "Electrochemical behavior of q235 steel in saltwater saturated with carbon dioxide based on new imidazoline derivative inhibitor," Corrosion Science, vol. 51, no. 1, pp. 102-109, 2009. doi: 10.1016/j. corsci.2008.09.036

[7] N. A. Octoviawan, "Study of effect of fluid flow rate on steel corrosion rate api 51 x-52 using polarization method on 3.5gas," Metallurgical Engineering and Materials UI, Depok, Indonesia, technical report, 2012.

[8] M. G. Fontana, Corrosion Engineering. New York, NY: McGraw-Hill Science, Engineering \& Mathematics, 1986.

[9] R. W. Revie, Corrosion and Corrosion Control: An Introduction to Corrosion Science and Engineering. New York, NY: John Wiley \& Sons, 2008.

[10] D. A. Jones, Principles and prevention of corrosion. New Yor, NY: Macmillan, 1992.

[11] A. W. Peabody et al., Control of pipeline corrosion. New York, NY: National Association of corrosion engineers, 1967.

[12] H.-h. Zhang, X. Pang, M. Zhou, C. Liu, L. Wei, and K. Gao, "The behavior of pre-corrosion effect on the performance of imidazoline-based inhibitor in 3 wt.\% NaCl solution saturated with $\mathrm{CO}_{2}$, " Applied Surface Science, vol. 356, pp. 63-72, 2015. doi: 10.1016/j.apsusc.2015.08.003

[13] D. Davies and G. Burstein, "The effects of bicarbonate on the corrosion and passivation of iron," Corrosion, vol. 36, no. 8, pp. 416-422, 1980. doi: 10.5006/0010-9312-36.8.416

[14] A. Mustafa, B. Ari-Wahjoedi, and M. Ismail, "Inhibition of $\mathrm{Co}_{2}$ corrosion of $\mathrm{x} 52$ steel by imidazoline-based inhibitor in high pressure $\mathrm{CO}_{2}$ water environment," Journal of Materials Engineering and Performance, vol. 22, no. 6, pp. 1748-1755, 2013. doi: 10.1007/s11665-012-0443-5

[15] Z. Ahmad, Principles of Corrosion Engineering and Corrosion Control. California, CA: Elsevier, 2006. 
[16] P. Bunruk, D. Kantachote, and A. Sukhoom, "Isolation and selection of purple non-sulfur bacteria for phosphate removal in rearing water from shrimp cultivation," Journal of Applied and Physical Sciences, vol. 3, no. 2, pp. 73-80, 2017. doi: 10.20474/japs-3.2.5

[17] Z. Azri, N. J. Ae, and Waristo, "Absorbance value of tobacco (Nicotiana Tabacum) essential oil to ultraviolet radiation in the way to investigate the potential of tobacco leaf for sunscreen substance," International Journal of Applied and Physical Sciences, vol. 3, no. 2, pp. 50-54, 2017. doi: 10.20469/ijaps.3.50005-2

[18] N. Mahmad, R. M. Taha, N. Rawi, and S. Mohajer, "The effects of picloram and 2,4-dichlorophenoxyacetic acid on induction of red coloured callus from celosia plumosa, an attractive ornamental plant," Journal of Applied and Physical Sciences, vol. 1, no. 1, pp. 9-12, 2015. doi: 10.20474/-japs1.1.2

[19] E. Olasehinde, S. Olusegun, A. Adesina, S. Omogbehin, and H. Momoh-Yahayah, "Inhibitory action of nicotiana tabacum extracts on the corrosion of mild steel in $\mathrm{HCl}$ : Adsorption and thermodynamics study," National Science, vol. 11, no. 1, pp. 83-90, 2013.

[20] B. A. Kurniawan, V. M. Pratiwi, and N. F. Ahmadi, "Effect of fluid flow, pH and tobacco extracts concentration as organic inhibitors to corrosion characteristics of AISI 1045 steel in 3.5\% $\mathrm{NaCl}$ environment containing $\mathrm{CO}_{2}$ gas," in Proceeding of AIP Conference, Seoul, Korea, 2018.

[21] P. R. Roberge, Handbook of Corrosion Engineering. New York, NY: McGraw-Hill,, 2000.

[22] G. Bhargava, T. Ramanarayanan, and S. Bernasek, "Imidazole- fe interaction in an aqueous chloride medium: Effect of cathodic reduction of the native oxide," Langmuir, vol. 26, no. 1, pp. 215-219, 2009. doi: 10.1021/la9020355

[23] S. D. Cramer and J. Bernard S. Covino, ASM Handbook Volume 13A: Corrosion: Fundamentals, Testing, and Protection. Geauga County, OH: ASM International, 2003.

[24] ASTM G31, Standard Practice for Laboratory Immersion Corrosion Testing of Metals. West Conshohocken, PA: ASTM Internasional, 2004.

[25] B. Mistry, A handbook of Spectroscopic Data. Bombay, India: Oxford Book Company, 2009.

[26] D. K. Yadav, M. Quraishi, and B. Maiti, "Inhibition effect of some benzylidenes on mild steel in $1 \mathrm{M} \mathrm{HCl:} \mathrm{An} \mathrm{experimental}$ and theoretical correlation," Corrosion Science, vol. 55, pp. 254-266, 2012. doi: 10.1016/j.corsci.2011.10.030

[27] L. Feng, H. Yang, and F. Wang, "Experimental and theoretical studies for corrosion inhibition of carbon steel by imidazoline derivative in $5 \% \mathrm{NaCl}$ saturated $\mathrm{Ca}(\mathrm{OH})_{2}$ solution," Electrochimica Acta, vol. 58, pp. 427-436, 2011. doi: 10.1016/j.electacta.2011.09.063

[28] G. Zhang, C. Chen, M. Lu, C. Chai, and Y. Wu, "Evaluation of inhibition efficiency of an imidazoline derivative in $\mathrm{CO}_{2}$-containing aqueous solution," Materials Chemistry and Physics, vol. 105, no. 2-3, pp. 331-340, 2007. doi: 10.1016/ j.matchemphys.2007.04.076

[29] D. Ortega-Toledo, J. Gonzalez-Rodriguez, M. Casales, L. Martinez, and A. Martinez-Villafañe, " $\mathrm{CO}_{2}$ corrosion inhibition of X-120 pipeline steel by a modified imidazoline under flow conditions," Corrosion Science, vol. 53, no. 11, pp. 3780-3787, 2011. doi: 10.1016/j.corsci.2011.07.028

[30] R. J. W. Hutasoit, Study of Imidazoline-based Corrosion Inhibitors Using Tafel Polarizatio. Depok, Indonesia: Metallurgical Engineering and Materials UI, 2013.

[31] K. Woie, "A study of the interaction between a kinetic hydrate inhibitor and selected corrosion inhibitors," master's thesis, University of Stavanger, Stavanger, Norway, 2011.

[32] X. Zhang, F. Wang, Y. He, and Y. Du, "Study of the inhibition mechanism of imidazoline amide on $\mathrm{CO}_{2}$ corrosion of Armco iron," Corrosion Science, vol. 43, no. 8, pp. 1417-1431, 2001. doi: 10.1016/s0010-938x(00)00160-8

[33] M. A. Malik, M. A. Hashim, F. Nabi, and Z. Al-Thabaiti, S. A. \& Khan, "Anti-corrosion ability of surfactants: A review," International Journal of Electrochemical Science, vol. 6, no. 6, pp. 1927-1948, 2011.

[34] Pine Research Instrument, "Study of mass transport limited corrosion using fpine rotating cylinder electrode," 2006. [Online]. Available: https://goo.gl/Jjdbxs

[35] M. F. Rahman, Effect of pH, and Rotation Speed on Corrosion Characteristics of Low Carbon Steels in Sulfuric Acid $\left(\mathrm{H}_{2} \mathrm{SO}_{4}\right)$ Solution Using Rotating Cylinder Electrode (RCE). Surabaya, Indonesia: Materials Engineering and Metallurgy ITS, 2015.

[36] I. Amalia, "Pengaruh variasi konsentrasi ekstrak daun jambu biji (psidium guajava) dan daun cengkeh (syizigium aromaticum) sebagai inhibitor organik pada api 51 grade b di lingkungan Nacl 3, 5\% ph4," Universitas Surabaya, Surabaya, Indonesia, Unpublished Doctoral dissertation, 2016. 
[37] D. Firmansyah, Study of Corrosion Inhibition of Carbon Steels in 1 M HCl Acidic Solution by Soursop Leaf Extract (Annona Muricata). Depok, Indonesia: Metallurgical Engineering and Materials UI, 2011.

[38] D. A. Lopez, S. N. Simison, and S. R. De Sanchez, "Inhibitors performance in $\mathrm{CO}_{2}$ corrosion: EIS studies on the interaction between their molecular structure and steel microstructure," Corrosion Science, vol. 47, no. 3, pp. 735-755, 2005. doi: 10.1016/j.apsusc.2004.03.247 